\title{
Preliminary Characterisation of Sardinian Red Grape Cultivars (Vitis vinifera L.) According to Their Phenolic Potential
}

\author{
V. Vacca ${ }^{1}$, A. Del Caro ${ }^{1 *}$, G.G. Milella ${ }^{1}$ and G. Nieddu ${ }^{2}$ \\ (1) Dipartimento di Scienze Ambientali Agrarie e Biotecnologie Agro-Alimentari, Università degli Studi di Sassari, Viale Italia 39, 07100 \\ Sassari, Italy \\ (2) Dipartimento di Economia e Sistemi Arborei, Università degli Studi di Sassari, Via Enrico De Nicola 9, 07100 Sassari, Italy
}

Submitted for publication: Feb 2009

Accepted for publication: May 2009

Key words: Cultivar, red grapes, polyphenolic composition, skins, seeds

Fourteen cultivars and clones, mainly selected from the island of Sardinia (Italy) and grown in a collection field, showed significant quantitative differences in phenolic potential. An extraction method designed to reproduce the winemaking process was used to determine the amounts of extractable polyphenols, anthocyanins, catechins and proanthocyanidins reactive to vanillin, and the proanthocyanidins in grape skins and seeds. The Sardinian cultivar Nieddera and the Spanish cultivar Graciano had the highest concentrations of extractable polyphenols, anthocyanins, catechins and proanthocyanidins reactive to vanillin. Four clones of the Cannonau cultivar (synonym Grenache) exhibited fairly high variability, with significant differences in berry and seed phenolic contents.

Historically, grape-growing has been one of the most important agricultural activities in Europe and has a great impact on the European economy. Innovations in agronomic, technological and marketing strategies have been adapted to optimise the quality of wines.

In the last ten years, there has been great interest in red grape cultivars throughout the world, especially in view of the scientific evidence for the so-called "French Paradox", which is associated with the antioxidant properties of the phenolic compounds in red grapes. In fact, the health benefits of red wines have been well documented in numerous scientific papers (Renaud \& De Logeril, 1992; Kanner et al., 1994; Burns et al., 2000; Lòpez-Vèlez et al., 2003; Corder et al., 2006). The importance of phenolic compounds for wine quality is also very well known, as they are responsible for important properties such as colour, bitterness and astringency (Gawel, 1998; Boulton, 2001; Brossaud et al., 2001).

In the last 40 years, the incidence of red cultivars has increased in Sardinia, a large island located in the Mediterranean Sea off southern Italy. Today, the most important red grape cultivar is Cannonau (synonym Grenache, cultivated in $31 \%$ of the 27000 -hectare regional vine-growing area), followed by the white grape cultivar Nuragus (15\% of the Sardinian vine-growing area), which for many decades was the main Sardinian cultivar. Other red grape cultivars grown in Sardinia are Monica and Carignano (12\% and $7 \%$ of the regional vine-growing area respectively) and Bovale and Pascale di Cagliari (6\% of the vine-growing area respectively) (Nieddu et al., 2006b). Other traditional Sardinian red grape cultivars like Girò and Cagnulari are currently showing a strong decline, with growing areas of less than 250 hectares. The reduction in grape genetic variability is due to the sharp decrease of the vine-growing area (in comparison to 74000 hectares in the 1980s) and the increasing spread of "international" cultivars like Sangiovese, Cabernet Sauvignon, Merlot and Syrah, which are characterised by very good adaptation to the environment and good technological and agronomical characteristics.

The traditional Sardinian range of varieties is not well characterised and there is information about the ampelographic patrimony of Sardinia, particularly the polyphenolic composition of red grape cultivars, regarding only a few cultivars (Castia et al., 1992a,b; Deidda et al., 1994; Del Caro et al., 1994). Moreover, it is very difficult to compare the data because they were obtained in different geographical areas and in vineyards subjected to different cultivation techniques, which could have influenced the productivity, berry size and area/volume ratio (Matthews et al., 1987; Matthews \& Matthews, 1988; Fernandez de Simon et al., 1992; Bergqvist et al., 2001).

Phenolic composition is used by scientists to differentiate wine cultivars (Mattivi et al., 1991; Castia et al., 1992b; De La PresaOwens et al., 1995; Gonzalez-Neves et al., 2001; Rossouw \& Marais, 2003). It is very important to know the concentration of phenolic compounds in grapes, both for cultivar characterisation and because of their role in the winemaking process. In fact, the total amount and the different concentrations of the various fractions give important information to oenologists with regard to the winemaking techniques that should be adopted for these grapes (Mattivi et al., 2002a).

The polyphenolic content is related to the grape composition and the oenological practices, and wine ageing can modify the phenolic composition (Fulcrand et al., 2006). Indeed, these compounds are involved in many chemical reactions during wine maturation and ageing that modify characteristics such as colour, flavour, taste (bitterness and astringency) and antioxidant activity (Pérez-Magariño \& Gonzales-SanJosè, 2004).

Wines with more stable and intense colour come from grapes with good phenolic maturity (Mattivi et al., 2002b; Jensen et al., 2008). Hence, grapes that produce wines suitable for ageing 
contain more phenolic compounds, especially anthocyanins and tannins with a low degree of polymerisation that are able to be transformed into proanthocyanidins or condensed tannins during storage. For this reason, grapes for wines to be aged for a long time should have a very high ratio between tannins with a low degree of polymerisation and those with a high degree of polymerisation.

There is very little information in the literature about the contribution of the polyphenolic compounds in the different parts of the grape to wine quality (Jensen et al., 2008). Therefore, the aim of this study was to characterise the most important Sardinian red grape cultivars according to the polyphenolic contents of the grape skins and seeds in order to evaluate their most appropriate oenological uses.

\section{MATERIALS AND METHODS}

\section{Sampling}

Research was carried out in 2007 on 14 grape cultivars collected during their technological maturity (soluble solids \%/titratable acidity ratio stable) and belonging to a varietal collection field planted at Sassari University's experimental agricultural station at Fenosu-Oristano (N 3953'42”, E 8³7'01”) in 2006. These cultivars were cultivated in three randomised plots (VSP trellised with gujot pruning, rootstock $1103 \mathrm{P}$, spacing $2.5 \mathrm{~m} \mathrm{x} 1 \mathrm{~m}$ ). The following red grape varieties and clones were studied: four Cannonau clones (CAPVS 1, CAPVS 2, CAPVS 5 selected in Sardinia and VCR1 selected in northern Italy) and the traditional Sardinian varieties Monica, Bovale grande, Pascale di Cagliari, Nieddera, Gregu nieddu, Caricagiola, Nieddu mannu and Girò. Two Spanish varieties, Mazuela and Graciano, which are genetically identical in 12 SSR markers to Carignano and Bovale sardo respectively but with a different adaptation to the environment, were included in the comparison (Nieddu et al., 2006a). Carignano and Bovale sardo could not be included in the study because they did not produce a sufficient number of homogeneous clusters during the study year, as required by the sampling protocol.

In September, 12 representative clusters per variety were sampled, one for each vine in the three plots. Clusters between $1 \mathrm{~m}$ and $20 \mathrm{~cm}$ above the soil were chosen. Titrable acidity, $\mathrm{pH}$ and total soluble solids were measured in musts of the different grape varieties. Two replicates of $500 \mathrm{~g}$ of berries for each variety were frozen at $-18^{\circ} \mathrm{C}$ until polyphenol extraction. The following were determined in the extracts of the grape skins and seeds: extractable polyphenols, extractable anthocyanins (only on skin extracts), catechins and proanthocyanidins reactive to vanillin, and extractable proanthocyanidins.

\section{Polyphenol extraction}

Various methods have been reported in the literature for the extraction of grape polyphenols (Di Stefano \& Cravero, 1991; Amrani \& Glories, 1994; Mattivi et al., 2002a). We adopted the Mattivi method, as it is able to extract polyphenols from grape skins and seeds, simulating the maceration process of red winemaking.

A $12 \%$ hydroalcoholic solution of ethyl alcohol with $5 \mathrm{~g} / \mathrm{L}$ of tartaric acid neutralised to $\mathrm{pH} 3$ with $\mathrm{NaOH}$, and supplemented with $200 \mathrm{mg} / \mathrm{L}$ of potassium metabisulphite, was prepared for the polyphenol extraction. Skins and seeds from $200 \mathrm{~g}$ of berries were manually separated and poured into two flasks, each containing $200 \mathrm{~mL}$ of hydroalcoholic solution. The flasks were put in a stove at $30^{\circ} \mathrm{C}$ for 5 days; each flask was stirred once a day. At the end of the extraction, the seed extract was directly poured into a 260 $\mathrm{mL}$ bottle, while the skin extract, obtained by gravity and manual pressing of the skins, was centrifuged for $8 \mathrm{~min}$ at $8000 \mathrm{rpm}$ to remove the lees and then poured into a $260 \mathrm{~mL}$ bottle. The bottles were filled with the hydroalcoholic solution, closed with a screw cap and stored at $4^{\circ} \mathrm{C}$ until the analysis.

\section{Spectrophotometric determinations}

Spectrophotometric determinations were carried out on the extracts according to the methods of Di Stefano et al. (1989), which allow isolation of the phenolic compounds on a Sep-Pak C18 cartridge to eliminate interference due to salts, sugars and proteins (HP 8453 UV-VIS spectrophotometer, Palo Alto, CA).

Extractable polyphenols: Extracts diluted with $1 \mathrm{~N}$ sulphuric acid were passed through a previously activated Sep-Pak cartridge and the phenolic compounds were eluted with $2 \mathrm{~mL}$ of methanol and $5 \mathrm{~mL}$ of water in $25 \mathrm{~mL}$ flasks. A volume of $1 \mathrm{~mL}$ of FolinCiocalteu reagent was added to the diluted samples, followed after 3 min by $4 \mathrm{~mL}$ of $10 \%$ sodium carbonate plus water up to volume. After $90 \mathrm{~min}$, the absorbance value was taken at $700 \mathrm{~nm}$ on a $1 \mathrm{~cm}$ cell against a blank obtained in the same way but with water instead of extract. The results $(\mathrm{mg} / \mathrm{kg}$ of grape) were expressed as $(+)$ catechin $=186.5^{*}$ E700 $* \mathrm{~d} ; \mathrm{d}=$ dilutions

Extractable anthocyanins: Extracts diluted with $1 \mathrm{~N}$ sulphuric acid were passed through a previously activated Sep-Pak cartridge. After washing of the cartridge with $0.01 \mathrm{~N}$ sulphuric acid, anthocyanins were eluted with $3 \mathrm{~mL}$ of methanol in $25 \mathrm{~mL}$ flasks; then $3 \mathrm{~mL}$ of $\mathrm{HCl}$ were added and made up to volume with a solution of ethanol:water:hydrochloric acid (70:30:1). The extractable anthocyanins were quantified on the basis of maximum absorbance in the visible light interval of 536 to 540 $\mathrm{nm}$ and calculated as malvidin $(\mathrm{mg} / \mathrm{kg}$ of grape $)=\mathrm{E}(1 \mathrm{~cm}, 1 \mathrm{max}$ vis) $* 26.6 * d$; $d=$ dilutions.

Extractable catechins and proanthocyanidins reactive to vanillin (Vanillin Index): After dilution with $1 \mathrm{~N}$ sulphuric acid, the samples were passed through a previously activated Sep-Pak cartridge and eluted with $5 \mathrm{~mL}$ of methanol; then $1 \mathrm{~mL}$ of this solution was poured into a dark glass flask, to which were added 6 $\mathrm{mL}$ of a $4 \%$ vanillin solution in methanol and the flask was placed in a cold water bath. After $3 \mathrm{~min}, 3 \mathrm{~mL}$ of $\mathrm{HCl}$ were added. A blank was prepared in the same way but with $6 \mathrm{~mL}$ of methanol instead of vanillin. Absorbance values at $500 \mathrm{~nm}$ were taken after $15 \mathrm{~min}$ and the results were expressed as $(+)$ catechin $(\mathrm{mg} / \mathrm{kg}$ of grape $)=290.8^{*} \Delta \mathrm{E}^{*} \mathrm{~d}$. $\Delta \mathrm{E}=$ difference in absorbance between sample and blank, $\mathrm{d}=$ dilutions.

Extractable proanthocyanidins: after dilution with $0.1 \mathrm{~N}$ sulphuric acid, $2 \mathrm{~mL}$ of diluted extracts were passed through a previously activated Sep-Pak cartridge, and proanthocyanidins were eluted with $3 \mathrm{~mL}$ of methanol and collected in $100 \mathrm{~mL}$ distillation flasks. $9.5 \mathrm{~mL}$ of absolute ethanol and $12.5 \mathrm{~mL}$ of hydrochloric acid containing $300 \mathrm{mg} / \mathrm{L}$ of $\mathrm{FeSO}_{4}: 7 \mathrm{H}_{2} \mathrm{O}$ were added to the flasks and they were heated in a bath of boiling water for $50 \mathrm{~min}$. The flasks were then put in a cold water bath in the dark for $10 \mathrm{~min}$. A blank was prepared in the same way but the flasks were not subjected to heating and the acid solution 
was added after chilling. The absorbance spectrum at 380 to $700 \mathrm{~nm}$ was recorded for both sample and blank. A tangent to the absorbance curve was plotted starting at the minimum point and ending at the maximum point. The height of the line drawn between the maximum and the tangent was read and expressed in absorbance units. The same procedure was followed for the blank. The difference between the two values (sample and blank) is the $\Delta \mathrm{E}$ '. For the final calculation, the content was expressed in cyanidin chloride $(\mathrm{mg} / \mathrm{kg}$ of grape $)=\Delta \mathrm{E}^{\prime} 1 \mathrm{~cm} * 1162.5 * \mathrm{~d} . \mathrm{d}=$ dilutions.

The values of the different parameters derive from calculations that consider the quantity of berries used, the millilitres of extract used, the molar extinction coefficients (obtained with calibration curves) and the molecular weights of the different compounds.

\section{Statistical analysis}

One-way analysis of variance (ANOVA) and HSD Tukey's test (significance level $\mathrm{p}<0.05$ ) were applied to the data (Statistica 6.0 for Windows).

\section{RESULTS AND DISCUSSION}

\section{Chemical parameters of musts}

The results reported in Table 1 indicate significant differences between the compared varieties. Most of them showed very low acidity and high $\mathrm{pH}$, typical of musts from grapes harvested in a warm climate and with a high sugar level. Mazuela had significantly higher acidity than all the other cultivars $(5.40 \mathrm{~g} / \mathrm{L}$ of tartaric acid); Bovale grande had the next highest value (4.61 $\mathrm{g} / \mathrm{L})$, while Gregu nieddu had the lowest value $(2.06 \mathrm{~g} / \mathrm{L})$.

The highest $\mathrm{pH}$ values were found in Graciano and Gregu nieddu (4.31 and 4.25 respectively), while the highest value among the
Cannonau clones was found in CAPVS1. Pascale di Cagliari had the lowest value for total soluble solids content (19.45\%), while Graciano and Monica showed significantly higher values (25.95 and $25.90 \%$ respectively). Among the four clones of Cannonau, CAPVS1 had the highest value $(24.95 \%)$ and VCR1 the lowest (20.90\%).

\section{Phenolic profiles of grape skin extracts}

The one-way ANOVA of grape skin phenolic profiles is reported in Table 2. The highest extractable phenolic contents were found in Nieddera, Graciano, Caricagiola, Cannonau CAPVS 1 and Bovale grande, while all the other cultivars had significantly lower values. The highest extractable anthocyanin content was found in Graciano, while the Cannonau clones VCR1 and CAPVS 2, and the Girò, Gregu nieddu and Pascale di Cagliari cultivars had lower values. The different cultivars showed fairly high variability in low molecular weight polyphenols (Vanillin Index). Extractable proanthocyanidins were significantly higher in Nieddera, Caricagiola and Cannonau CAPVS 5 than in all the other varieties.

\section{Phenolic profiles of seed extracts}

The contents of different phenolic classes in the seeds are reported in Table 3. Nieddera had a significantly higher value of extractable polyphenols than the other cultivars, while Mazuela had the lowest value. Graciano showed a significantly higher content of catechins reactive to vanillin than the other cultivars, confirming what has been reported in the literature (Monagas et al., 2003); Bovale grande and Mazuela had the lowest values. In contrast, the content of extractable proanthocyanidins was significantly higher in Monica than in the other cultivars, while Bovale grande and Mazuela had the lowest values.

\section{TABLE 1}

Titratable acidity, $\mathrm{pH}$ and total soluble solids of the different cultivars (means \pm standard deviations).

\begin{tabular}{|c|c|c|c|}
\hline Cultivar & $\begin{array}{l}\text { Titratable acidity } \\
\text { (g/L tartaric acid) }\end{array}$ & $\mathbf{p H}$ & $\begin{array}{c}\text { Total soluble solids } \\
\text { ( }{ }^{\circ} \text { Brix \%) }\end{array}$ \\
\hline Cannonau CAPVS 1 & $3.19 \pm 0.05 \mathrm{fg}^{*}$ & $3.90 \pm 0.00 \mathrm{~cd}$ & $24.95 \pm 0.07 \mathrm{c}$ \\
\hline Cannonau CAPVS 2 & $3.71 \pm 0.06 c$ & $3.81 \pm 0.00 \mathrm{e}$ & $24.10 \pm 0.00 \mathrm{~d}$ \\
\hline Cannonau CAPVS 5 & $3.22 \pm 0.00 \mathrm{f}$ & $3.82 \pm 0.01 \mathrm{de}$ & $24.10 \pm 0.00 \mathrm{~d}$ \\
\hline VCR1 biotype Tocai rosso & $3.30 \pm 0.00 \mathrm{ef}$ & $3.77 \pm 0.01 \mathrm{efg}$ & $20.90 \pm 0.00 \mathrm{~h}$ \\
\hline Bovale grande & $4.61 \pm 0.06 b$ & $3.69 \pm 0.01 \mathrm{~g}$ & $20.00 \pm 0.00 \mathrm{i}$ \\
\hline Caricagiola & $3.04 \pm 0.05 \mathrm{~g}$ & $4.18 \pm 0.04 b$ & $23.50 \pm 0.00 \mathrm{e}$ \\
\hline Girò & $3.34 \pm 0.05 \mathrm{def}$ & $4.19 \pm 0.01 b$ & $25.50 \pm 0.07 b$ \\
\hline Gregu Nieddu & $2.06 \pm 0.06 \mathrm{~h}$ & $4.25 \pm 0.01 \mathrm{ab}$ & $23.55 \pm 0.07 \mathrm{e}$ \\
\hline Monica & $3.34 \pm 0.05 \mathrm{def}$ & $3.98 \pm 0.04 \mathrm{c}$ & $25.90 \pm 0.00 \mathrm{a}$ \\
\hline Nieddera & $3.82 \pm 0.00 \mathrm{c}$ & $3.96 \pm 0.01 \mathrm{c}$ & $22.70 \pm 0.00 \mathrm{f}$ \\
\hline Nieddu Mannu & $3.67 \pm 0.00 \mathrm{c}$ & $3.79 \pm 0.02 \mathrm{ef}$ & $21.55 \pm 0.07 \mathrm{~g}$ \\
\hline Pascale di Cagliari & $3.49 \pm 0.05 \mathrm{~d}$ & $3.94 \pm 0.01 \mathrm{c}$ & $19.45 \pm 0.071$ \\
\hline Graciano & $3.41 \pm 0.06 \mathrm{de}$ & $4.31 \pm 0.02 \mathrm{a}$ & $25.95 \pm 0.07 \mathrm{a}$ \\
\hline Mazuela & $5.40 \pm 0.00 \mathrm{a}$ & $3.71 \pm 0.04 \mathrm{fg}$ & $17.95 \pm 0.07 \mathrm{~m}$ \\
\hline
\end{tabular}

* Values are the mean of two replicates for each extraction.

Data followed by different letters within each column differ significantly according to HSD Tukey's Test at $p<0.05$. 
TABLE 2

Phenolic profile in the skins of different cultivars of red grapes ( $\mathrm{mg} / \mathrm{kg}$ of grape).

\begin{tabular}{|c|c|c|c|c|}
\hline Cultivar & $\begin{array}{l}\text { Extractable polyphenols } \\
\text { (mg/kg of catechin) }\end{array}$ & $\begin{array}{l}\text { Extractable anthocyanins } \\
\text { (mg/kg malvidin) }\end{array}$ & $\begin{array}{c}\text { Vanillin Index } \\
\text { (mg/kg of catechin) }\end{array}$ & $\begin{array}{l}\text { Extractable proanthocyanidins } \\
\text { (mg/kg of cyanidin chloride) }\end{array}$ \\
\hline Cannonau CAPVS 1 & $1074 \mathrm{ab} *$ & $431 \mathrm{e}$ & $966 \mathrm{abc}$ & $915 \mathrm{~cd}$ \\
\hline Cannonau CAPVS 2 & $812 \mathrm{def}$ & $304 \mathrm{gh}$ & 919abcd & $907 \mathrm{~cd}$ \\
\hline Cannonau CAPVS 5 & 791def & $404 \mathrm{efg}$ & $881 \mathrm{abcd}$ & $1611 \mathrm{ab}$ \\
\hline $\begin{array}{l}\text { Cannonau } \\
\text { VCR1 biotipo } \\
\text { Tocai rosso }\end{array}$ & $632 \mathrm{ef}$ & $257 \mathrm{~h}$ & $564 \mathrm{cde}$ & $911 \mathrm{~cd}$ \\
\hline Bovale grande & $1034 \mathrm{abc}$ & $888 b$ & $682 \mathrm{bcde}$ & $1236 \mathrm{bc}$ \\
\hline Caricagiola & $1156 a$ & $417 \mathrm{ef}$ & $1025 \mathrm{ab}$ & $1715 \mathrm{a}$ \\
\hline Girò & $889 \mathrm{bcd}$ & $270 \mathrm{~h}$ & 713 bcde & $1075 \mathrm{c}$ \\
\hline Gregu Nieddu & $599 \mathrm{f}$ & $321 \mathrm{fgh}$ & $717 \mathrm{bcde}$ & $641 \mathrm{de}$ \\
\hline Monica & $721 \mathrm{def}$ & $576 d$ & $660 \mathrm{bcde}$ & $448 \mathrm{ef}$ \\
\hline Nieddera & $1224 \mathrm{a}$ & $735 c$ & $1231 \mathrm{a}$ & $1717 \mathrm{a}$ \\
\hline Nieddu Mannu & $702 \mathrm{def}$ & $634 \mathrm{~cd}$ & $375 \mathrm{e}$ & $1093 c$ \\
\hline Pascale di Cagliari & 754def & 347 efgh & 686bcde & $1249 b c$ \\
\hline Graciano & $1212 \mathrm{a}$ & $2468 \mathrm{a}$ & $1010 \mathrm{ab}$ & $547 f$ \\
\hline Mazuela & 819 cde & $701 \mathrm{c}$ & $545 \mathrm{de}$ & $1092 \mathrm{c}$ \\
\hline
\end{tabular}

* Values are the mean of two replicates for each extraction.

Data followed by different letters within each column differ significantly according to HSD Tukey's Test at $p<0.05$.

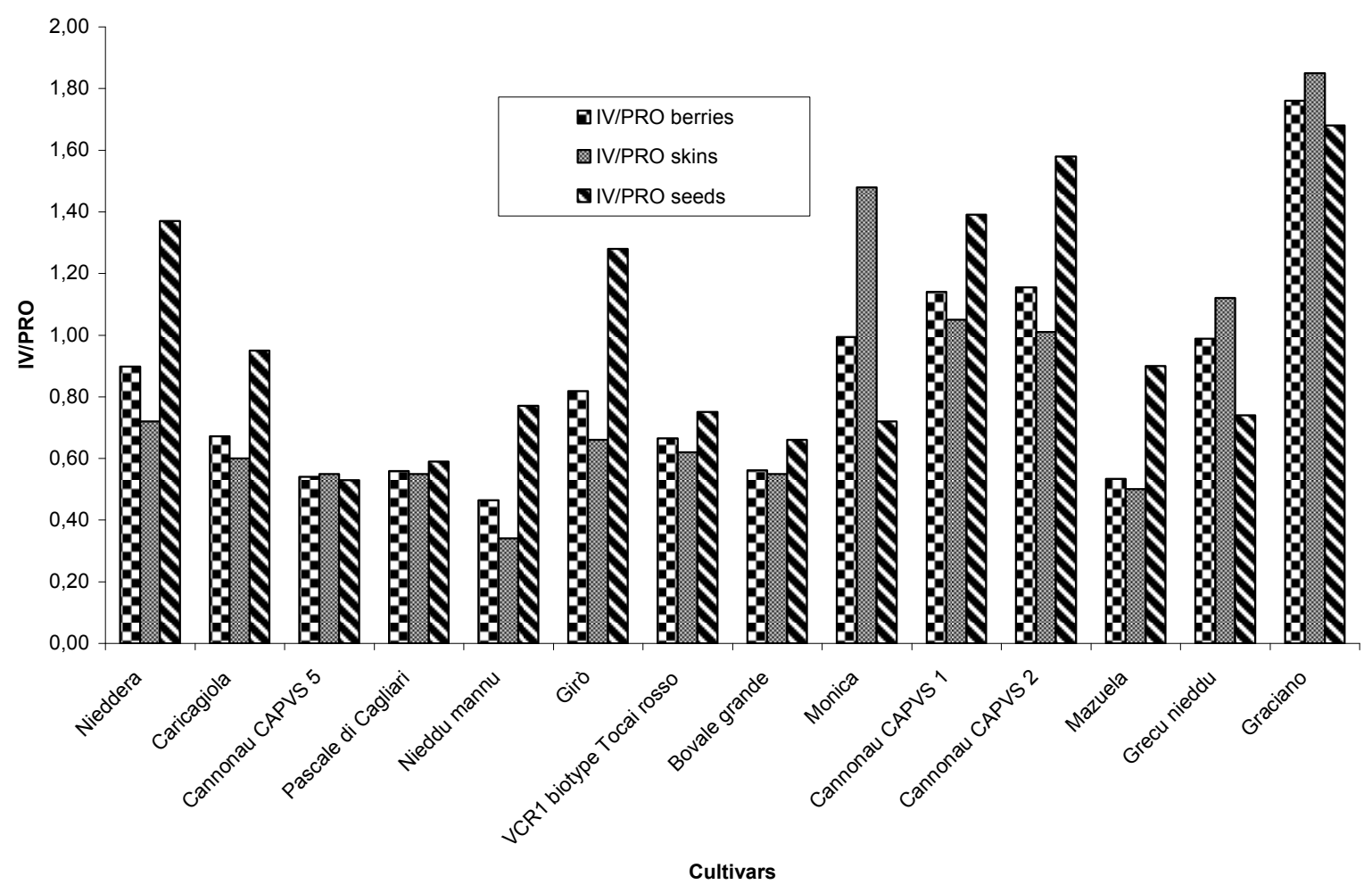

FIGURE 1

IV/PRO ratio of berries, skins and seeds in different red grape cultivars. 
TABLE 3

Phenolic profile in the seeds of different cultivars of red grapes (mg/kg of grape)

\begin{tabular}{lccc}
\hline Cultivar & $\begin{array}{c}\text { Extractable polyphenols } \\
\text { (mg/kg of catechin) }\end{array}$ & $\begin{array}{c}\text { Vanillin index } \\
\text { (mg/kg of catechin) }\end{array}$ & $\begin{array}{c}\text { Extractable proanthocyanidins } \\
\text { (mg/kg of cyanidin chloride) }\end{array}$ \\
\hline Cannonau CAPVS 1 & $40 *^{*} \mathrm{c}$ & $440 \mathrm{cde}$ & $317 \mathrm{gh}$ \\
Cannonau CAPVS 2 & $440 \mathrm{c}$ & $476 \mathrm{~cd}$ & $301 \mathrm{~h}$ \\
Cannonau CAPVS 5 & $368 \mathrm{~cd}$ & $212 \mathrm{fg}$ & $398 \mathrm{ef}$ \\
Cannonau & $415 \mathrm{c}$ & $364 \mathrm{def}$ & $484 \mathrm{c}$ \\
VCR1 biotipo & $131 \mathrm{ef}$ & $77 \mathrm{~h}$ & $117 \mathrm{i}$ \\
Tocai rosso & $415 \mathrm{c}$ & $440 \mathrm{cde}$ & $464 \mathrm{~cd}$ \\
Bovale grande & $454 \mathrm{c}$ & $460 \mathrm{cde}$ & $358 \mathrm{fg}$ \\
Caricagiola & $259 \mathrm{de}$ & $243 \mathrm{f}$ & $328 \mathrm{gh}$ \\
Girò & $619 \mathrm{~b}$ & $578 \mathrm{c}$ & $799 \mathrm{a}$ \\
Gregu Nieddu & $852 \mathrm{a}$ & $909 \mathrm{~b}$ & $664 \mathrm{~b}$ \\
Monica & $366 \mathrm{~cd}$ & $338 \mathrm{ef}$ & $432 \mathrm{de}$ \\
Nieddera & $250 \mathrm{def}$ & $226 \mathrm{fg}$ & $383 \mathrm{ef}$ \\
Nieddu Mannu & $635 \mathrm{~b}$ & $1093 \mathrm{a}$ & $651 \mathrm{~b}$ \\
Pascale di Cagliari & $93 \mathrm{f}$ & $94 \mathrm{gh}$ & $105 \mathrm{i}$ \\
Graciano & & & \\
Mazuela & & & \\
\hline
\end{tabular}

*Values are the mean of two replicates for each extraction.

Data followed by different letters within each column differ significantly according to HSD Tukey's Test at $p<0.05$.

\section{TABLE 4}

Range of extractable polyphenols contents in different red grape cultivars.

\begin{tabular}{ll}
\hline Range & Cultivar \\
\hline $800-1100^{*}$ & $\begin{array}{l}\text { Gregu nieddu, Mazuela, Pascale di Cagliari, VCR1 biotype } \\
\text { Tocai rosso, Nieddu mannu }\end{array}$ \\
$1100-1400$ & $\begin{array}{l}\text { Cannonau CAPVS 5, Bovale grande, Cannonau CAPVS 2, } \\
\text { Monica, Girò }\end{array}$ \\
$1400-1700$ & Cannonau CAPVS 1, Caricagiola \\
$1700-2000$ & Graciano \\
$>2000$ & Nieddera \\
\hline
\end{tabular}

*Data are expressed as catechin, mg/kg of grape.

\section{Extractable polyphenols in the berries}

Extractable polyphenols varied from $859 \mathrm{mg} / \mathrm{kg}$ in Gregu nieddu grapes to $2076 \mathrm{mg} / \mathrm{kg}$ in Nieddera grapes (Table 4). The different cultivars were distributed in five groups of increasing value. Ten of the 14 cultivars were in the low-value groups (five from 800 to $1100 \mathrm{mg} / \mathrm{kg}$, five from 1100 to $1400 \mathrm{mg} / \mathrm{kg}$ ), while the other four varieties showed higher concentrations (Nieddera, Graciano, Caricagiola and Cannonau CAPVS 1). In a comparison with a large number of Italian red grape varieties, with values ranging from 1500 to $4200 \mathrm{mg} / \mathrm{kg}$ (Mattivi et al., 2002b), the Sardinian
TABLE 5

Range of extractable anthocyanin content in different red grape cultivars.

\begin{tabular}{ll}
\hline Range & Cultivar \\
\hline $200-400^{*}$ & $\begin{array}{l}\text { Girò, Cannonau VCR1 biotype Tocai rosso, Cannonau } \\
\text { CAPVS 2, Gregu nieddu, Pascale di Cagliari }\end{array}$ \\
$400-600$ & $\begin{array}{l}\text { Cannonau CAPVS 5, Caricagiola, Cannonau CAPVS 1, } \\
\text { Monica }\end{array}$ \\
$600-800$ & Nieddu mannu, Mazuela, Nieddera \\
$800-1000$ & Bovale grande \\
$1000-2500$ & Graciano \\
\hline
\end{tabular}

*Data are expressed as malvidin 3-monoglucoside chloride, $\mathrm{mg} / \mathrm{kg}$ of grape.

red grapes exhibit a medium or low-medium level of polyphenols. This comparison is particularly significant, as our results were obtained with the same methods of extraction and analysis of the different phenolic classes, although we used frozen grapes instead of fresh grapes.

Therefore, we can conclude that only Nieddera, Graciano, Caricagiola and Cannonau CAPVS 1 can yield wines suitable for long ageing, as confirmed by the excellent ageing possibilities reported for Graciano (Nunez et al., 2004). The other varieties are indicated more for young, fruity wines. 


\section{TABLE 6}

Range of extractable catechins and proanthocyanidins reactive to vanillin content in different red grape cultivars.

\begin{tabular}{ll}
\hline Range & Cultivar \\
\hline $600-1000^{*}$ & $\begin{array}{l}\text { Mazuela, Nieddu mannu, Bovale grande, Pascale of } \\
\text { Cagliari, Cannonau VCR1 biotype Tocai rosso, } \\
\text { Gregu nieddu }\end{array}$ \\
$1000-1400$ & Cannonau CAPVS 5, Girò, Monica, Cannonau CAPVS 2 \\
$1400-1800$ & Cannonau CAPVS 1, Caricagiola \\
$1800-2200$ & Nieddera, Graciano \\
\hline
\end{tabular}

*Data are expressed as catechin, $\mathrm{mg} / \mathrm{kg}$ of grape.

\section{TABLE 7}

Range of extractable proanthocyanidin content in different red grape cultivars.

\begin{tabular}{ll}
\hline Range & Cultivar \\
\hline $700-1000^{*}$ & Gregu nieddu \\
$1000-1300$ & $\begin{array}{l}\text { Graciano, Mazuela, Cannonau CAPVS 2, Cannonau } \\
\text { CAPVS 1, Monica }\end{array}$ \\
$1300-1600$ & $\begin{array}{l}\text { Bovale grande, Cannonau VCR1 biotype Tocai rosso, Girò, } \\
\text { Nieddu mannu }\end{array}$ \\
$1600-1900$ & Pascale di Cagliari \\
$1900-2200$ & Cannonau CAPVS 5, Caricagiola \\
$2200-2500$ & Nieddera \\
\hline
\end{tabular}

*Data are expressed as cyanidin chloride, $\mathrm{mg} / \mathrm{kg}$ of grape.

\section{Extractable anthocyanins in the berries}

Table 5 shows a similar situation to the above-mentioned phenolic class, with nine of 14 varieties having a very low anthocyanin content (200 to $600 \mathrm{mg} / \mathrm{kg}$ ), and four varieties with mean concentrations of between 600 and $1000 \mathrm{mg} / \mathrm{kg}$. Only Graciano had a very high anthocyanin content $(2464 \mathrm{mg} / \mathrm{kg})$. The nine cultivars with low contents could be indicated for monovarietal wines with low or medium colour intensity. In fact, even if the maceration time is extended, the extraction from the skins is very quick (Mattivi et al., 2003). However, these cultivars could also be used to produce rosé and red wines, the latter from the more coloured varieties. Nieddu mannu, Mazuela, Nieddera, Bovale grande and obviously Graciano, which contain medium and high concentrations of anthocyanins, are the varieties most indicated to produce strongly coloured wines (Nunez et al., 2004).

Extractable catechins and proanthocyanidins reactive to vanillin (Vanillin Index) in the berries

In Table 6, the cultivars are separated into four groups at intervals of $400 \mathrm{mg} / \mathrm{kg}$, ranging from a minimum of $639 \mathrm{mg} / \mathrm{kg}$ for Mazuela to a maximum of $2163 \mathrm{mg} / \mathrm{kg}$ for Graciano. Again, most varieties were in the low-value groups (Mazuela, Nieddu mannu, Bovale

\section{TABLE 8}

Percentage of extractable catechins and proanthocyanidins reactive to vanillin and extractable proanthocyanidins in the seeds of the different red grape cultivars. The remaining percentage is localised in the skins.

\begin{tabular}{|c|c|c|}
\hline Cultivar & $\begin{array}{c}\% \text { Extractable } \\
\text { catechins and } \\
\text { proanthocyanidins } \\
\text { reactive to vanillin }\end{array}$ & $\begin{array}{c}\% \text { Extractable } \\
\text { proanthocyanidins }\end{array}$ \\
\hline Cannonau CAPVS 1 & 31.3 & 25.7 \\
\hline Cannonau CAPVS 2 & 34.1 & 24.9 \\
\hline Cannonau CAPVS 5 & 19.4 & 19.8 \\
\hline $\begin{array}{l}\text { Cannonau } \\
\text { VCR1 biotype } \\
\text { Tocai rosso }\end{array}$ & 39.2 & 34.7 \\
\hline Bovale grande & 10.1 & 8.6 \\
\hline Caricagiola & 30.0 & 21.3 \\
\hline Girò & 39.2 & 25.0 \\
\hline Gregu Nieddu & 25.3 & 33.9 \\
\hline Monica & 46.7 & 64.1 \\
\hline Nieddera & 42.5 & 27.9 \\
\hline Nieddu Mannu & 47.1 & 28.3 \\
\hline Pascale di Cagliari & 24.8 & 23.5 \\
\hline Graciano & 52.0 & 54.3 \\
\hline Mazuela & 14.7 & 8.8 \\
\hline
\end{tabular}

grande, Pascale, Cannonau VCR1 biotype Tocai rosso, Gregu nieddu), while the other cultivars showed higher values.

\section{Extractable proanthocyanidins in the berries}

In Table 7, the cultivars are separated into six groups at intervals of $300 \mathrm{mg} / \mathrm{kg}$, from a minimum of $969 \mathrm{mg} / \mathrm{kg}$ for Gregu nieddu to a maximum of $2381 \mathrm{mg} / \mathrm{kg}$ for Nieddera. Nine of the varieties $(>50 \%)$ are in the intermediate concentration (1000 to $1600 \mathrm{mg} / \mathrm{kg}$ ).

We also calculated the Vanillin Index/proanthocyanidin ratio (VI/PRO), as it is correlated with the degree of polymerisation of flavanols and thus effectively describes the condensation reaction course. In fact, this ratio is defined as the "tannin condensation index": the lower the ratio, the higher the tannin molecular weight and hence the degree of polymerisation of these compounds. Contrarily, if the ratio is high, the degree of polymerisation of flavanols is lower and these molecules are more reactive and astringent (Cagnasso et al., 2005, 2006). For this reason, only varieties with a high value of this ratio (from 0.8 upwards) are considered suitable for wines that can withstand a decrease in the tannic character and thus a softening of the taste during storage (Mattivi et al., 1991). In our cultivars (Fig. 1), the mean value of the ratio was 0.84 ( 0.77 without Graciano), with extreme values 
of 0.46 for Nieddu mannu and 1.76 for Graciano. As reported in the literature, the flavanols in the seeds are less polymerised than those in the skins (Prieur et al., 1994; Souquet et al., 1996). This is confirmed by our results for 10 of the 14 varieties analysed, although Cannonau CAPVS 5, Gregu nieddu, Monica and Graciano presented higher values in the skins. In particular, Graciano had a very high VI/PRO ratio for the skins (1.85), indicating a higher content of monomeric and/or low molecular weight flavonols (Monagas et al., 2003).

\section{Distribution of catechins and proanthocyanidins in the berries}

Table 8 shows that 10 of the 14 varieties had less than $40 \%$ of the catechins and proanthocyanidins reactive to vanillin located in the seeds; among them, Mazuela, Bovale and especially Cannonau CAPVS 5 had a very low percentage in the seeds. Of the other four varieties, only Graciano exceeded 50\% located in the seeds. The content of extractable proanthocyanidins in the seeds did not exceed $35 \%$ in 12 of the 14 varieties; only Monica and Graciano exhibited a high percentage in the seeds.

\section{CONCLUSIONS}

The analysis of the phenolic potential of the main Sardinian red grape cultivars resulted in a better technological characterisation, which could be useful to improve wine production. Nieddera is distinguished by the high concentration of extractable polyphenols, extractable anthocyanins (together with Bovale grande and Nieddu Mannu), catechins and proanthocyanidins reactive to vanillin, and extractable proanthocyanidins (together with Caricagiola and the Cannonau CAPVS 5 clone). This cultivar can be considered very good for wines suitable for long ageing. Its aptitude is confirmed by the VI/PRO ratio, which shows a high value $(0.90)$ due to cultivar's richness in monomeric and/or low molecular weight phenols. Regarding the Spanish Graciano and Mazuela varieties, cultivated in Sardinia, only the former deserves attention on account of its high anthocyanin content and its VI/PRO ratio, the highest among all the cultivars, confirming its suitability for wines that are suitable for long ageing. The best use for the other cultivars would be the production of young wines or those to be aged for a medium term, although in the latter case great attention would have to be given to the use of suitable winemaking procedures or blending with grapes with a high phenolic content.

\section{LITERATURE CITED}

Amrani, J.K. \& Glories, Y., 1994. Etude en conditions modeles de l'extractibilitè des composes pheoliques des pellicules et des pepins de raisins rouges. J. Int. Vigne et Vin 28, 303-317.

Bergqvist, J., Dokoozlian, N. \& Ebisuda N., 2001. Sunlight exposure and temperature effects on berry growth and composition of Cabernet Sauvignon and Grenache in the central San Joaquin Valley of California. Am. J. Enol. Vitic. 52, 1-7.

Boulton, R., 2001. The co-pigmentation of anthocyanins and its role in the color of red wines: a critical review. Am. J. Enol. Vitic. 52, 67-87.

Brossaud, F., Cheynier, V. \& Noble, A.C., 2001. Bitterness and astringency of grape and wine polyphenols. Austr. J. Grape Wine Res. 7, 33-39.

Burns, J., Gardner, P., O’Neil, J., Crawford, S., Morecroft, I., McPhail, D.B., Lister, C., Matthews, D., MacLean, M.R., Lean, M.E.J., Duthie, G.G. \& Crozier, A., 2000. Relationship among antioxidant activity, vasodilataton capacity, and phenolic content of red wines. J. Agric. Food Chem., 48, 220-230.

Cagnasso, E., Caudana, A., Rolle, L. \& Gerbi, V., 2005-2006. Valutazione delle potenzialità fenoliche di uve rosse piemontesi. Quad. Vitic. Enol., Univ. Torino $28,61-73$.
Castia, T., Franco, M.A., Mattivi, F., Muggiolu, G., Sferlazzo, G. \& Versini, G., 1992a. Valutazione mediante metodi statistici multivariati dell'evoluzione di alcuni parametri compositivi di uve "Cabernet sauvignon" e "Cannonau" allevate a spalliera ed a tendone in Sardegna. Riv. Merceol. 31, 81-94.

Castia, T., Franco, M.A., Mattivi, F., Muggiolu, G., Sferlazzo, G. \& Versini, G., 1992b. Characterization of grapes cultivated in Sardinia: chemometrics methods applied to the anthocyanic fraction. Sciences des Aliments, 2, 239-255.

Corder, R., Mullen, W., Khan, N.Q., Marks, S.C., Wood, E.G., Carrier, M.J. \& Crozier, A., 2006. Oenology: red wine procyanidins and vascular health. Nature 444, 566.

Deidda, P., Nieddu, G., Pellizzaro, G. \& Pia, G., 1994. Dynamics of the anthocyanins in "Cannonau" grapevine as related to the environmental conditions. Polyphenols 94. 17th Int. Conf. on Polyphenols, May 23-17, Palma de Mallorca, Spain.

De La Presa-Owens, C., Lamuela-Raventos, R. M., Buxaderas, S. \& De La TorreBoronat, M.C., 1995. Differentiation and grouping characteristics of varietal grape musts from Penedes Region (I). Am. J. Enol. Vitic. 46, 283-291.

Del Caro, A., Franco, M. A., Sferlazzo, G., Mattivi, F., Versini G., Monetti, A. \& Castia, T., 1994. La caratterizzazione del profilo anocianico di cultivar di Vitis vinifera della Sardegna. Vignevini, XXI/11, 63-69.

Di Stefano, R. \& Cravero, M.C., 1991. Metodi per lo studio dei polifenoli dell'uva. Riv. Vitic. Enol. 2, 37-45.

Di Stefano, R., Cravero, M.C. \& Gentilizi, N., 1989. Metodi per lo studio dei polifenoli del vino. L'Enotecnico, Maggio, 83-89.

Fernandez de Simon, B., Hernandez, T. \& Estrella, I., 1992. Relationship between chemical structure and biosynthesis and accumulation of certain phenolic compounds in grape skins during ripening. Z. Lebensm. Unters. Forsch. 195, 124-128.

Fulcrand, H, Duenas, M., Salasa, E. \& Cheynier, V., 2006. Phenolic reactions during winemaking and aging. Am. J. Enol. Vitic. 57, 289-297.

Gawel, R., 1998. Red wine astringency: a review. Austr. J. Grape Wine Res. 4, 74-95.

Gonzales-Neves, G., Gomez-Cordoves, C. \& Barreiro, L., 2001. Anthocyanic composition of Tannat, Cabernet Sauvignon and Merlot young red wines from Uruguay. J. Wine Res. 12, 125-133.

Jensen, J.S., Demiray, S., Egebo, M. \& Meyer, A.S., 2008. Prediction of wine color attributes from the phenolic profiles of red grapes (Vitis vinifera). J. Agric. Food Chem. 56, 1105-1115.

Kanner, J., Frankel, E.N., Granit, R., German, B. \& Kinsella, J.E., 1994. Natural antioxidants in grapes and wines. J. Agric. Food Chem. 42, 64-69.

Lòpez-Vèlez, M., Martìnez-Martìnez, F. \& Del Valle-Ribes, C., 2003. The study of phenolic compounds as natural antioxidant in wine. Crit. Rev. Food Sci. Nutr. 43, 233-244.

Matthews, M.A. \& Anderson, M.M., 1988. Fruit ripening in Vitis vinifera L.: responses to seasonal water deficits. Am. J. Enol. Vitic. 39, 313-320.

Matthews, M.A.,Anderson, M.M. \& Schultz, H.R., 1987. Phenologic and growth responses to early and late season water deficits in Cabernet franc. Vitis 26, 147-160.

Mattivi, F., Nicolini, G. \& Sanchez, C., 1991. Confronto tra il contenuto polifenolico di vini Marzemino, Pinot nero e Sangiovese dell'annata 1989. Riv. Vitic. Enol. 1, 39-52.

Mattivi, F., Prast, A., Nicolini, G. \& Valenti, L., 2002a. Validazione di un nuovo metodo per la misura del potenziale polifenolico delle uve rosse e discussione del suo campo di applicazione in enologia. Riv. Vitic. Enol. 2/3, 55-74.

Mattivi, F., Prast, A., Nicolini, G. \& Valenti, L., 2003. Il potenziale polifenolico delle uve rosse e la sua applicazione in enologia. L'Enologo October, 105-114.

Mattivi, F., Zulian, C., Nicolini, G. \& Valenti, L., 2002b. Wine, biodiversity, technology, and antioxidants. Ann. N.Y. Acad. Sci. 957, 37-56.

Monagas, M., Gomez-Cordoves, C., Bartolomè, B., Laureano, O. \& Ricardo da Silva, J.M., 2003. Monomeric, oligomeric, and polymeric flavan-3-ol composition of wines and grapes from Vitis vinifera L. cv Graciano, Tempranillo and Cabernet Sauvignon. J. Agric. Food Chem. 51, 6475-6481.

Nieddu, G., Chessa, I., Cocco, G.F., Nieddu, M. \& Deidda, P., 2006 a. Caratterizzazione mediante marcatori RAPD dei vitigni tradizionali della Sardegna. Italus Hortus 13, 275-280.

Nieddu G., Nieddu M., Erre P. \& Chessa, I., 2006b. Recupero e conservazione dei vitigni minori della Sardegna. Convegno nazionale vitigni minori, Torino. 
Nunez, V., Monagas, M., Gomez-Cordoves, M.C. \& Bartolomè, B., 2004. Vitis vinifera L. cv Graciano grapes characterized by its anthocyanin profile. Postharvest Biol. and Technol. 31, 69-79.

Pérez-Magariño, S. \& Gonzàlez Sanjosè, M.L., 2004. Evolution of flavanols, anthocyanins, and their derivatives during the aging of red wines elaborated from grapes harvested at different stages of ripening. J. Agric. Food Chem. 52, 1181-1189.

Prieur, C., Rigaud, J., Cheynier, V. \& Moutounet, M., 1994. Poligomeric and polymeric procyanidins from grape seeds. Phytochem. 36, 781-784.
Renaud, S. \& De Logeril, M., 1992. Wine, alcohol, platelets, and the French Paradox for coronary heart disease. Lancet 339, 1523-1526.

Rossouw, M. \& Marais, J., 2003. Phenolic compounds in South African red wines: a preliminary study. www. Wynboer.co.za, February.

Souquet, J.M., Cheynier, V., Brossaud, F. \& Moutounet, M., 1996. Polymeric proanthocyanidins from grape skins. Phytochem. 43, 509-512.' 